\title{
Financial indicators to evaluate the economic performance of feedlot steers with different slaughter weights
}

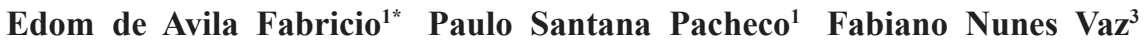 \\ Daniel Batista Lemes ${ }^{2}$ Angelina Camera ${ }^{2}$ Gabriella Ibarra Ocaña Machado ${ }^{2}$
}

\author{
${ }^{1}$ Departamento de Zootecnia, Universidade Federal de Santa Maria (UFSM), 97105-900, Santa Maria, RS, Brasil. E-mail: edomfabricio@gmail.com. \\ ${ }^{*}$ Correspondig author. \\ ${ }^{2}$ Departamento de Zootecnia, Universidade Federal de Santa Maria (UFSM), Santa Maria, RS, Brasil. \\ ${ }^{3}$ Departamento de Educação Agrícola e Extensão Rural, Universidade Federal de Santa Maria (UFSM), Santa Maria, RS, Brasil.
}

\begin{abstract}
The objective of this study was to evaluate various financial indicators, estimated deterministically (considering historical quotes twelve consecutive years - 2003 to 2014), on the economic feasibility of finishing steers commercialized with different weights, using the simulation technique. Performance data steers were simulated with average initial weight of $350 \mathrm{~kg}$, fed in feedlot and slaughtered with 410, 440, 470,500, 530, 560 and 590kg. The feeding period varies from 46 to 185 days, respectively. Based in various economic indicators, the viability of the investment decreased linearly according to the increase in slaughter weight. The coefficient of simple linear regression and means from lowest to highest slaughter weight were, respectively: net present value $(-0.538$ and $R \$ 67.37, R \$ 65.28, R \$ 32.14, R \$-7.34$, $R \$ 8.01, R \$-12.38, R \$-23.41)$; index benefit: cost (-0.0003 and $R \$ 1.042, R \$ 1.039, R \$ 1.014, R \$ 1.006, R \$ 1.003, R \$ 0.995, R \$ 0.991)$; additional return on investment $(-0.009$ and $1.38,1.29,0.35,0.11,0.05,-0.08,-0.13 \%$ per month); internal rate of return (-0.009 and 2.21, $2.10,1.28,0.80,0.93,0.78,0.73 \%$ per month). Feedlot use as termination option to obtain the direct benefits of this technology is an alternative investment with low economic return.
\end{abstract}

Key words: economic analysis, beef cattle, investment projects, intensive systems, microeconomics.

Indicadores financeiros na avaliação do desempenho econômico do confinamento de novilhos com diferentes pesos de abate

RESUMO: O objetivo deste estudo foi avaliar diversos indicadores financeiros estimados de forma determinística (considerando cotações históricas de doze anos consecutivos - 2003 a 2014) na viabilidade econômica da terminação de novilhos em confinamento, comercializados em diferentes pesos, utilizando a técnica de simulação. Foram simulados dados de desempenho de novilhos com peso médio inicial de $350 k g$, alimentados em confinamento para serem abatidos com 410, 440, 470, 500, 530, 560 e 590kg. O periodo de alimentação variou de 46 a 185 dias, respectivamente. Baseada em vários indicadores, a viabilidade do investimento diminuiu linearmente de acordo com o aumento do peso. $O$ coeficiente de regressão linear simples e as médias do menor para o maior peso de abate foram, respectivamente: valor presente líquido $(-0,538$ e $R \$ 67,37, R \$ 65,28, R \$ 32,14, R \$-7,34, R \$ 8,01, R \$-12,38, R \$-23,41)$; índice beneficio: custo $(-0,0003$ e $R \$ 1,042, R \$ 1.039, R \$$ $1,014, R \$ 1,006, R \$ 1,003, R \$ 0,995, R \$ 0,991)$; retorno adicional sobre o investimento $(-0,009$ e $1,38,1,29,0,35,0,11,0,05,-0,08,-0,13 \%$ a.m.); taxa interna de retorno (-0,009 e 2,21, 2,10, 1,28, 0,80, 0,93, 0,78, 0,73\% a.m.). O uso do confinamento como opção de terminação, visando obter os beneficios diretos desta tecnologia, representa a alternativa de investimento com baixo retorno econômico.

Palavras-chave: análise econômica, bovinos de corte, projetos de investimento, sistemas intensivos, microeconomia.

\section{INTRODUCTION}

In today's agribusiness scenario in Brazil, where agriculture is shown competitive and has advanced on livestock areas, finishing cattle in feedlot becomes a potential investment option, it allows a significant increase of beef production per unit area and the possibility to integrate other activities.

RESTLE et al. (2007) commented that among other factors, the epoch planned for sale and slaughter weight are closely related to the profitability of the feedlot. In the study of PACHECO et al. (2014a), increase in slaughter weight resulted in a high possibility of economic unsuccessful of feedlot activity, although at lighter weights would not be possible to obtain carcasses with adequate degree of subcutaneous fat thickness. Thus, a strategic evaluation considering variation in the time of sale and slaughter weight can aid in the definition the best economic investment results.

Although being considered high cost of technology, the use of feedlot has increased in production units throughout Brazil (FERREIRA et al., 2009; MOREIRA et al., 2009; LOPES et 
al., 2013). This characteristic has motivated the development of studies on the economic viability, enabling decision making between investing or not, prior to implementation of the investment project.

In this way, the economic evaluation methods become important auxiliary tools in decision making. Economic analysis considering various financial indicators together is suggested by SOUZA \& CLEMENTE (2009), which according to the authors, resulted in more consistent information for risk assessment and his confrontation with the possibility of return. However, this methodology is still under used in animal production.

The objective of this study was to evaluate various financial indicators, estimated deterministically, on the economic feasibility of finishing steers commercialized with different weights, using the simulation technique.

\section{MATERIALS AND METHODS}

The experiment was conducted in the Department of Animal Science, Universidade Federal de Santa Maria, Rio Grande do Sul state, Brazil. The economic viability of feedlot was evaluated by deterministic analysis (using items from static costs and revenues), considering historical quotes of twelve consecutive years (2003-2014).

Performance data steers were simulated to reach slaughter weights of 410,440, 470, 500, 530, 560 and $590 \mathrm{~kg}$ live weight from the initial average weight of $350 \mathrm{~kg}$.

A diet was formulated for each slaughter weight (Table 1), considering the same ingredients, but in different proportions aiming at meeting the nutritional necessity of each weight range, according to the average daily gain weight established. For this, the BR-Corte $2^{\circledR}$ software - available online by VALADARES FILHO et al. (2012) - was used, determining the nutritional requirements and formulating diets. Ingredients included in the concentrate were ground corn, soybean meal, urea and minerals. The roughage was corn silage. Formulated diets obtained $78 \%$ of Total Digestible Nutrients (TDN) and 14\% of crude protein (CP), with a forage: concentrate ratio of 30:70, as described by OLIVEIRA \& MILLEN (2014) as an average value of use in Brazilian feedlots.

Marketing of animals was scheduled to occur in the month of July (premiums or discounts were not considered), period where the finished cattle has the highest prices in Rio Grande do Sul state

Table 1 - Experimental diet (as a percentage of dry matter - DM) and performance of technical coefficients according to the slaughter weight.

\begin{tabular}{|c|c|c|c|c|c|c|c|}
\hline \multirow{2}{*}{ Items } & \multicolumn{7}{|c|}{ } \\
\hline & 410 & 440 & 470 & 500 & 530 & 560 & 590 \\
\hline & \multicolumn{7}{|c|}{ - } \\
\hline Corn silage, $\%$ & 32.00 & 32.00 & 32.00 & 32.00 & 32.00 & 32.00 & 32.00 \\
\hline Corn grain, $\%$ & 57.56 & 58.25 & 60.20 & 59.53 & 59.94 & 60.51 & 60.87 \\
\hline Soybean meal, \% & 8.51 & 7.86 & 5.78 & 6.54 & 6.07 & 5.53 & 5.11 \\
\hline Urea, $\%$ & 1.18 & 1.16 & 1.30 & 1.22 & 1.30 & 1.28 & 1.35 \\
\hline Minerals, \% & 0.75 & 0.73 & 0.72 & 0.70 & 0.69 & 0.68 & 0.67 \\
\hline \multicolumn{8}{|c|}{${ }^{-1}$} \\
\hline Roughage intake, kg DM day ${ }^{-1}$ & 2.03 & 2.08 & 2.14 & 2.17 & 2.22 & 2.26 & 2.31 \\
\hline Concentrate intake, $\mathrm{kg}$ DM day ${ }^{-1}$ & 5.77 & 5.91 & 6.09 & 6.17 & 6.31 & 6.43 & 6.57 \\
\hline Intake, $\%$ live weight (LW) & 2.05 & 2.02 & 2.01 & 1.96 & 1.94 & 1.91 & 1.89 \\
\hline Feeding time, days & 46.00 & 69.00 & 92.00 & 115.00 & 138.00 & 162.00 & 185.00 \\
\hline Number of periods, months & 3.00 & 3.00 & 4.00 & 5.00 & 6.00 & 6.00 & 7.00 \\
\hline Month of purchase feeder steer & May & May & Apr & Mar & Feb & Feb & Jan \\
\hline Feeder steer, $\mathrm{R} \$ \mathrm{~kg}^{-1} \mathrm{LW}$ & 3.17 & 3.17 & 3.17 & 3.20 & 3.06 & 3.06 & 2.96 \\
\hline Finished cattle, $\mathrm{R} \$ \mathrm{~kg}^{-1} \mathrm{LW}$ & 3.60 & 3.60 & 3.60 & 3.60 & 3.60 & 3.60 & 3.60 \\
\hline Roughage, $\mathrm{R} \$ \mathrm{~kg}^{-1} \mathrm{DM}^{* *}$ & 0.37 & 0.37 & 0.37 & 0.37 & 0.37 & 0.37 & 0.37 \\
\hline Concentrate, $\mathrm{R} \$ \mathrm{~kg}^{-1} \mathrm{DM}^{* *}$ & 0.61 & 0.59 & 0.59 & 0.58 & 0.58 & 0.58 & 0.57 \\
\hline $\mathrm{ADG}^{* * *}, \mathrm{~kg}$ animal ${ }^{-1}$ day $^{-1}$ & 1.30 & 1.30 & 1.30 & 1.30 & 1.30 & 1.30 & 1.30 \\
\hline
\end{tabular}

"Based on average body weight between initial weight and slaughter weight. ${ }^{* *}$ Considering a purchase at the beginning of the period based on the average price of the year. ${ }^{* * *}$ Average daily gain. 
(ANUALPEC, 2015). In this way, beginning of feedlot was simulated according to weight gain $(1.3 \mathrm{~kg} /$ day $)$ and the predetermined slaughter weight, as verified in the studies of VAZ et al. (2013), ARGENTA et al. (2014) and OLIVEIRA \& MILLEN (2014) - this last research conducted with 31 consultants in several states of Brazil. To determine the date of purchase of steers the following equation was used: month of purchase $=$ sales month-((initial slaughter weight $) /$ average daily gain/30). How not to have a daily or weekly quotation of the price of feeder steers, a few treatments have obtained the same cost of feeder steer, because the calculated period needed for termination returned to a different number of days, with the onset in the same month. These coefficients are shown in table 1.

The different slaughter weights were considered investment projects mutually exclusive. To estimate costs, revenues and financial indicators (estimated per animal), were used the average values practiced in Rio Grande do Sul State, in the years 2003-2014, deflated for 2014 by the IGP-DI of Getúlio Vargas Foundation. The data have been obtained from the following sources: CONAB - National Supply Company, IEA - Institute of Agricultural Economy of São Paulo, EMATER / RS-ASCAR and ANUALPEC - Brazilian Livestock Yearbook. For purposes of conversion, was considered R $\$ 1.00=$ US\$ 0.35 .

For classification of cost items, revenue and calculation of financial indicators was utilized the methodology proposed by PACHECO et al. (2014a). Facility costs were estimated for static capacity of 1,000 animals and lifespan of 25 years. Depreciation (facilities, machinery, implements and equipments) were calculated for a planning horizon of one year. Opportunity costs were calculated considering the minimum rate of attractiveness (TMA) of $0.8687 \%$ per month (equivalent of $10.91 \%$ per year) based on the average basic rate SELIC (Special System of Clearance and Custody) in the year of 2014. The opportunity cost of capital invested was obtained by the sum of operating expenses (feeder cattle purchase, health control, roughage, concentrate, labor and additional expenses) for the period corresponding to the number of months stipulated for each slaughter weight.

For the opportunity cost of land (referring only to the area designated for the feedlot facility), was considered the possibility at the annual rental equivalent to $3 \%$ of the average hectare value (R\$ 9,370.19) for agriculture in the region of Santa Maria/ Cachoeira do Sul in the last 12 years (ANUALPEC, 2015). It was determined for each confined animal $0.025 \mathrm{ha}$ which is equivalent to taking advantage of 40 animals per hectare.
The health control consisted of the application of veterinary products for controlling ectoparasites (ivermectin 1\%), and vaccination against foot and mouth disease in dose per animal according to the manufacturer's recommendations. Feed cost was obtained by the product of the total consumption of roughage and concentrate $(\mathrm{kg}$ DM animal ${ }^{-1}$ ) for their respective costs $\mathrm{kg}^{-1} \mathrm{DM}$ and this cost was considered in its totality at the period zero in cash flow.

For cost estimates with labor, considered the need of 1 man for 500 animals, receiving a minimum wage plus burdens, and for technical assistance remunerated in two minimum wages per month for every 1,000 animals (average minimum wage from 2003 to 2014, $\mathrm{R} \$ 593.00$ ). Ten days were added to the feeding period for the preparation and maintenance of facilities, machinery and equipments. Costs of additional expenses (maintenance of facilities, machinery, implements and equipments + fuel + electricity + shipping + office supplies + taxes) were estimated for the equivalent of $3 \%$ of the mentioned operating cost.

Fixed costs $\quad(\mathrm{FC}=$ depreciation $\quad+$ opportunity of facilities, machinery, implements and equipment + land opportunity) and variable costs $(\mathrm{VC}=$ feeder cattle + health + roughage + concentrate + labor + technique assistance + additional + capital opportunity), effective operational cost $(\mathrm{EOC}=\mathrm{VC}$ - capital opportunity), total operational cost (TOC= EOC + depreciation), total cost $(\mathrm{TC}=\mathrm{FC}+\mathrm{VC})$, gross revenue ( $\mathrm{GR}=$ revenue with fat cattle sale), gross margin ( $\mathrm{GM}=\mathrm{GR}-\mathrm{EOC})$, net margin ( $\mathrm{NM}=$ GR-TOC), profit (GR-TC), cost $/ \mathrm{kg}$ weight gain, cost/@ weight gain, net present value (NPV), index benefit: cost (IB:C), additional return on investment (ROIA); Internal Rate of Return (IRR) and payback period (payback) discounted (PBd) were obtained as presented equations for PACHECO et al. (2014a) and SOUZA \& CLEMENTE (2009).

For simulation, tabulation and data analysis was used the Microsoft ${ }^{\circledR}$ Excel software (Microsoft, Redmond, WA). Data were submitted to simple linear regression analysis. Mathematical model employed in the analysis was: $\hat{\mathrm{y}}_{\mathrm{ij}}=\beta_{0}+\beta_{1} \mathrm{SW}_{\mathrm{i}}+\mathrm{e}_{\mathrm{ij}}$, where: $\hat{\mathrm{y}}_{\mathrm{ij}}=$ estimated dependent variables, $\beta_{0}=$ intercept, $\beta_{1}=$ regression coefficient, $\mathrm{SW}_{\mathrm{i}}=$ slaughter weight $(\mathrm{kg}), \mathrm{e}_{\mathrm{ij}}$ $=$ random error $\left(\sim \mathrm{NID}, 0, \sigma^{2}\right)$.

\section{RESULTS AND DISCUSSION}

Variable costs (Table 2) increased with increasing slaughter weight, mainly due to the increase 
in the cost of feed (roughage + concentrate). Among the variable costs, the purchase of the feeder steers was the item of greatest impact in the lighter weights, reducing its relative importance as the animals have been traded heaviest. This result reflected the increase in feed cost associated with decline in the cost of feeder steer, since the higher slaughter weight greater the fattening period. Thus, purchase of lean animals took place an increasingly earlier each year, a time when quotations are lower compared to other months according to ANUALPEC (2015). PACHECO et al. (2014a) confirmed that feed costs, acquisition and sale of animal prices are responsible for much of the variation in the economic viability of feedlot.

Financial indicators (Table 3) EOC, TOC, TC and GR showed positive and significant regression coefficients. The increase in slaughter weight did not significantly influence the GM and NM. Many times, economic analysis made superficially observing just GM or $\mathrm{MN}$ values can classify an investment as feasible. However, the costs of depreciation, not considered in the calculation of GM, and opportunity cost of capital and land, not considered in NM are important to confirm conditions that the activity has to remain for a longer time without decapitalizing the investor.
Profit per animal has been decreasing according to increased slaughter weight, according to estimates of the regression equation. A similar behavior has been verified for profit per hectare, limiting the same weight. This indicator also showed a strong point of feedlot, demonstrating good results by area, when the result is positive per animal. In a study with young steers (FERREIRA et al., 2009) and steers (PACHECO et al., 2014b) there was a greater viability in shorter periods of confinement, agreeing with the results of this research.

There was a decreasing behavior in the NPV per animal, turning negative after $534 \mathrm{~kg}$ of slaughter weight, according to regression equation. This indicator reflects the return on monetary investment values measured by the difference between the present value of cash inflows and the present value of cash outflows, submitted to a certain discount rate (TMA) (KASSAI et al., 2007). In this case, it indicated that from $534 \mathrm{~kg}$ of slaughter weight, the investment should not be executed from the economic point of view because his return will be less than TMA.

In other research evaluating slaughter weights (PACHECO et al., 2012, 2014a), lighter weights showed better economic results through the

Table 2 - Cost items and revenue estimated in R\$ per animal according to the slaughter weight $(\mathrm{R} \$ 1.00=\mathrm{US} \$ 0.35)$.

\begin{tabular}{|c|c|c|c|c|c|c|c|c|}
\hline \multirow{2}{*}{ Items } & \multicolumn{7}{|c|}{ - } & \multirow{2}{*}{$\mathrm{CV}, \%$} \\
\hline & 410 & 440 & 470 & 500 & 530 & 560 & 590 & \\
\hline Fixed costs ${ }^{1}$ & 6.1 & 8.6 & 11.2 & 13.8 & 16.4 & 19.0 & 21.7 & 0.40 \\
\hline Depreciation $^{* 2}$ & 4.9 & 6.9 & 8.9 & 10.9 & 12.9 & 14.9 & 16.9 & 0.00 \\
\hline Opportunity $^{* 3}$ & 0.1 & 0.2 & 0.3 & 0.4 & 0.6 & 0.7 & 1.0 & 0.00 \\
\hline Land Opportunity $^{4}$ & 1.1 & 1.5 & 2.0 & 2.4 & 2.9 & 3.3 & 3.8 & 0.00 \\
\hline Variable costs ${ }^{5}$ & $1,379.2$ & $1,496.1$ & $1,626.0$ & $1,762.5$ & $1,841.2$ & $1,980.1$ & $2,086.6$ & 0.80 \\
\hline Feeder cattle $^{6}$ & $1,108.5$ & $1,108.5$ & $1,110.6$ & $1,121.6$ & $1,069.7$ & $1,069.7$ & $1,035.8$ & 1.75 \\
\hline Health & 4.4 & 4.4 & 4.4 & 4.4 & 4.4 & 4.4 & 4.4 & 0.00 \\
\hline Roughage $^{7}$ & 34.5 & 53.0 & 72.9 & 92.2 & 113.2 & 134.7 & 157.1 & 1.64 \\
\hline Concentrate $^{8}$ & 162.4 & 243.0 & 331.1 & 415.6 & 506.1 & 598.9 & 693.4 & 1.25 \\
\hline Labor $^{9}$ & 5.6 & 8.0 & 10.3 & 12.6 & 14.9 & 17.3 & 19.6 & 0.00 \\
\hline Technique assistance ${ }^{10}$ & 2.2 & 3.1 & 4.0 & 5.0 & 5.9 & 6.8 & 7.7 & 0.00 \\
\hline Additional $^{11}$ & 39.5 & 42.6 & 46.0 & 49.5 & 51.4 & 55.0 & 57.5 & 0.88 \\
\hline Capital opportunity ${ }^{12}$ & 22.0 & 33.5 & 46.7 & 61.6 & 75.7 & 93.5 & 111.1 & 4.05 \\
\hline Total $\cos \mathrm{t}^{13}$ & $1,385.3$ & $1,504.7$ & $1,637.1$ & $1,776.2$ & $1,857.6$ & $1,999.2$ & $2,108.3$ & 0.79 \\
\hline Gross revenue ${ }^{14}$ & $1,475.0$ & $1,582.9$ & $1,690.9$ & $1,798.8$ & $1,906.7$ & $2,014.6$ & $2,122.6$ & 0.00 \\
\hline
\end{tabular}

${ }^{*}$ Considering cost of facilities, machinery, implements and equipment.

${ }^{1} \hat{\mathrm{Y}}=-29.6+0.087^{*} \mathrm{PA}, \mathrm{R}^{2}=1, \mathrm{P}<0.01 ;{ }^{2} \hat{\mathrm{Y}}=-22.56+0.067^{*} \mathrm{PA}, \mathrm{R}^{2}=1, \mathrm{P}<0.01 ;{ }^{3} \hat{\mathrm{Y}}=-1.98+0.005^{*} \mathrm{PA}, \mathrm{R}^{2}=0.975, \mathrm{P}<0.01 ;{ }^{4} \hat{\mathrm{Y}}=-5.06+0.015^{*} \mathrm{PA}$, $\mathrm{R}^{2}=1, \mathrm{P}<0.01 ;{ }^{5} \hat{\mathrm{Y}}=-228.64+3.93^{*} \mathrm{PA}, \mathrm{R}^{2}=0.998, \mathrm{P}<0.01 ;{ }^{6} \hat{\mathrm{Y}}=1289.62-0.40^{*} \mathrm{PA}, \mathrm{R}^{2}=0.690, \mathrm{P}=0.0206 ;{ }^{7} \hat{\mathrm{Y}}=-246.22+0.68^{*} \mathrm{PA}, \mathrm{R}^{2}=0.999$, $\mathrm{P}<0.01 ;{ }^{8} \hat{\mathrm{Y}}=-1054.47+2.95^{*} \mathrm{PA}, \mathrm{R}^{2}=0.999, \mathrm{P}<0.01 ;{ }^{9} \hat{\mathrm{Y}}=-26.07+0.077^{*} \mathrm{PA}, \mathrm{R}^{2}=1, \mathrm{P}<0.01 ;{ }^{10} \hat{\mathrm{Y}}=-10.24+0.03^{*} \mathrm{PA}, \mathrm{R}^{2}=1, \mathrm{P}<0.01 ;{ }^{11} \hat{\mathrm{Y}}=-$ $1.29+0.10^{*} \mathrm{PA}, \mathrm{R}^{2}=0.996, \mathrm{P}<0.01 ;{ }^{12} \hat{\mathrm{Y}}=-184.32+0.49^{*} \mathrm{PA}, \mathrm{R}^{2}=0.995, \mathrm{P}<0.01 ;{ }^{13} \hat{\mathrm{Y}}=-258.23+4.02{ }^{*} \mathrm{PA}, \mathrm{R}^{2}=0.998, \mathrm{P}<0.01 ;{ }^{14} \hat{\mathrm{Y}}=0+3.597^{*} \mathrm{PA}$, $\mathrm{R}^{2}=1, \mathrm{P}<0.01$. 
Table 3 - Estimated financial indicators per animal according to the slaughter weight $(\mathrm{R} \$ 1.00=\mathrm{US} \$ 0.35)$.

\begin{tabular}{|c|c|c|c|c|c|c|c|c|}
\hline \multirow{2}{*}{ Financial indicators } & \multicolumn{7}{|c|}{ 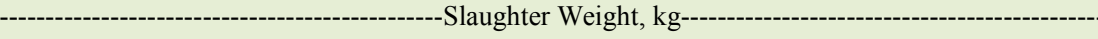 } & \multirow{2}{*}{$\mathrm{CV}, \%$} \\
\hline & 410 & 440 & 470 & 500 & 530 & 560 & 590 & \\
\hline EOC, $\mathrm{R} \$$ animal $^{-1} 1$ & $1,357.2$ & $1,462.6$ & $1,579.3$ & $1,700.9$ & $1,765.5$ & $1,886.6$ & $1,975.5$ & 0.88 \\
\hline TOC, $\mathrm{R} \$$ animal $^{-12}$ & $1,362.1$ & $1,469.5$ & $1,588,2$ & $1,711.8$ & $1,778.4$ & $1,901.6$ & $1,992.4$ & 0.88 \\
\hline $\mathrm{TC}, \mathrm{R} \$ \mathrm{~kg}^{-1} \mathrm{LW}^{3}$ & 3.38 & 3.42 & 3.48 & 3.55 & 3.50 & 3.57 & 3.57 & 0.92 \\
\hline $\mathrm{TC}, \mathrm{R} \$ \mathrm{~kg}^{-1} \mathrm{WG}^{4}$ & 23.09 & 16.72 & 13.64 & 11.84 & 10.32 & 9.52 & 8.78 & 15.60 \\
\hline $\mathrm{TC}, \mathrm{R} \$ @^{-1} \mathrm{WG}^{5}$ & 692.65 & 501.56 & 409.28 & 355.25 & 309.60 & 285.59 & 263.53 & 15.60 \\
\hline $\mathrm{GM}, \mathrm{R} \$$ animal $^{-1}$ & 117.77 & 120.32 & 111.56 & 97.91 & 141.20 & 127.99 & 147.07 & 12.01 \\
\hline $\mathrm{NM}, \mathrm{R} \$$ animal $^{-1}$ & 112.88 & 113.42 & 102.65 & 87.00 & 128.28 & 113.06 & 130.13 & 13.18 \\
\hline Profit, $\mathrm{R} \$$ animal $^{-16}$ & 89.69 & 78.24 & 53.72 & 22.54 & 49.10 & 15.47 & 14.31 & 30.18 \\
\hline Profit, $\mathrm{R} \$ \mathrm{ha}^{-17}$ & $3,587.65$ & $3,129.47$ & $2,148.61$ & 901.72 & $1,964.16$ & 618.94 & 572.22 & 30.18 \\
\hline $\mathrm{NPV}, \mathrm{R} \$$ animal $^{-18}$ & 67.37 & 65.28 & 32.14 & -7.34 & 8.01 & -12.38 & -23.41 & 74,83 \\
\hline $\mathrm{IB}: \mathrm{C}, \mathrm{R} \$^{9}$ & 1.042 & 1.039 & 1.014 & 1.006 & 1.003 & 0.995 & 0.991 & 0.65 \\
\hline ROIA, $\%$ a.m. ${ }^{10}$ & 1.38 & 1.29 & 0.35 & 0.11 & 0.05 & -0.08 & -0.13 & 68.21 \\
\hline IRR,\% a.m. ${ }^{11}$ & 2.21 & 2.10 & 1.28 & 0.80 & 0.93 & 0.78 & 0.73 & 24.41 \\
\hline IRR:TMA ${ }^{12}$ & 2.55 & 2.42 & 1.47 & 0.92 & 1.07 & 0.90 & 0.84 & 24.41 \\
\hline PBd, months ${ }^{13}$ & 2.88 & 2.89 & 3.94 & 4.97 & 5.98 & 6.03 & 7.06 & 7.03 \\
\hline
\end{tabular}

${ }^{1} \hat{\mathrm{Y}}=-44.31+3.4399^{*} \mathrm{PA}, \mathrm{R}^{2}=0.996, \mathrm{P}<0.01 ;{ }^{2} \hat{\mathrm{Y}}=-66.87+3.506{ }^{*} \mathrm{PA}, \mathrm{R}^{2}=0.996, \mathrm{P}<0,01 ;{ }^{3} \hat{\mathrm{Y}}=2.96+0.0012^{*} \mathrm{PA}, \mathrm{R}^{2}=0.851, \mathrm{P}<0,01 ;{ }^{4} \hat{\mathrm{Y}}=49.51-$ 0.072 ${ }^{*} \mathrm{PA}, \mathrm{R}^{2}=0.851, \mathrm{P}<0,01 ;{ }^{5} \hat{\mathrm{Y}}=1,485.23-2.165^{*} \mathrm{PA}, \mathrm{R}^{2}=0.857, \mathrm{P}<0,01 ;{ }^{6} \hat{\mathrm{Y}}=203.91-0.357^{*} \mathrm{PA}, \mathrm{R}^{2}=0.768, \mathrm{P}<0,01 ;{ }^{7} \hat{\mathrm{Y}}=10,329.34-16.966{ }^{*} \mathrm{PA}$, $\mathrm{R}^{2}=0.824, \mathrm{P}<0,01 ;{ }^{8} \hat{\mathrm{Y}}=287.44-0.538^{*} \mathrm{PA}, \mathrm{R}^{2}=0.884, \mathrm{P}<0,01 ;{ }^{9} \hat{\mathrm{Y}}=1.16-0.0003^{*} \mathrm{PA}, \mathrm{R}^{2}=0.912, \mathrm{P}<0,01 ;{ }^{10} \hat{\mathrm{Y}}=4.93-0.009^{*} \mathrm{PA}, \mathrm{R}^{2}=0.828, \mathrm{P}<0.01$; ${ }^{11} \hat{\mathrm{Y}}=5.68-0.009^{*} \mathrm{PA}, \mathrm{R}^{2}=0.807, \mathrm{P}<0.01 ;{ }^{12} \hat{\mathrm{Y}}=6.56-0.010^{*} \mathrm{PA}, \mathrm{R}^{2}=0.807, \mathrm{P}<0.01 ;{ }^{13} \hat{\mathrm{Y}}=-7.6+0.025 * \mathrm{PA}, \mathrm{R}^{2}=0.964, \mathrm{P}<0.01$.

NPV financial indicator. SOUZA \& CLEMENTE (2009) stated that, for sure, NPV is the investment analysis technique most widely known and employed; however, in research on economic evaluation in beef cattle area, it is still not found, making difficult results comparisons.

COAN et al. (2008) commented that considering a system where the feedlot is integrated with other production activities, even when the economic outcome is similar to the financial application (TMA), you should choose to use, since the indirect benefits justify its adoption.

Another important indicator is the IB: $\mathrm{C}$ or profitability index, a measure of how much is expected to earn per unit of capital invested at the end of the planning horizon (SOUZA \& CLEMENTE, 2009). This research showed a decreasing behavior, the best return has been obtained in lighter weight ( $\mathrm{R} \$ 1.042)$, indicating a return of $\mathrm{R} \$ 0.991$ in the last slaughter weight for each R\$ 1,000 invested. Similar results (decrease of the IB: $\mathrm{C}$ with increasing slaughter weight) were reported by MELLO et al. (2009) and PACHECO et al. (2012, 2014a). For this indicator, for that the project has viability, the maximum weight of fattening estimated by regression equation was $545 \mathrm{~kg}$.

In terms of profitability through the IB:C, it can be expected the lightest slaughter weight,
$4.2 \%$ of real profitability at the end of the project. However, this rate did not allow an immediate comparison with the TMA $(0.87 \%$ a.m. $)$. Equivalent rate for the same period is the ROIA, which as SOUZA \& CLEMENTE (2009) is the best estimate of profitability because informs the value obtained beyond the application of capital in the TMA in percentage per period. In this study, a linear decrease according to increased slaughter weight, and weight estimated by regression equation as the limit for a positive result has been $548 \mathrm{~kg}$.

IRR is a way to also evaluate the risk of the investment, which is the rate that equals the NPV to zero, thus being greater than the TMA indicating viability in the project, conversely the closer the TMA, the greater was the risk of getting a NPV equal to zero (SOUZA \& CLEMENTE, 2009). In this paper the IRR was decreasing and became lower than the TMA after $544 \mathrm{~kg}$ of slaughter weight, according to the regression equation. This comparison is shown in the index IRR:TMA. In their study, PACHECO et al. (2014a) reported a negative IRR, unlike PACHECO et al. (2012) in which the IRR overcame TMA.

Regarding $\mathrm{PBd}$, according SOUZA \& CLEMENTE (2009) is classified as risk indicator, which means that the greater PBd relative to the investment horizon, greater is the risk. There was an 
increase in PBd with the increase in slaughter weight, according to regression analysis. Cash flow of this study has now a conventional behavior, because it presents several negative periods becoming positive only in the last period, when revenue is thus always present in the final payback period, indicating a high risk investment.

\section{CONCLUSION}

Based on the financial indicators used in this study in a joint manner, investment has become less economically feasible with increasing slaughter weight. Considering the costs of items and revenue estimated from annual prices from 2003 to 2014, the use of confinement as finishing option to obtain the direct benefits of this technology is an alternative investment with low economic return. The simulation technique is an important tool to assist in decision making previously of implementation of investment projects in feedlot.

\section{ACKNOWLEDGEMENTS}

We thanks the Coordenação de Aperfeiçoamento de Pessoal de Nível Superior (CAPES) and the Conselho Nacional de Desenvolvimento Científico e Tecnológico $(\mathrm{CNPq})$ for providing the financial support required for this study.

\section{REFERENCES}

ANUALPEC. Anualpec 2015: anuário da pecuária brasileira. São Paulo, SP: Informa Economics FNP, 2015. 280p.

ARGENTA, F.M. et al. Steers performance fed diets with Alexander grass silage (Urochloa plantaginea) x sorghum silage (Sorghum bicolor (L.) Moench). Semina: Ciências Agrárias, v.35, n.2, p.951, 2014. Available from: <http://goo.gl/cErVwB >. Accessed: Aug. 10, 2015. doi: 10.5433/1679-0359.2014v35n2p951.

COAN, R.M. et al. Economical viability, performance, and carcass characteristics of confined steers fed palisadegrass silage, tanzaniagrass silage or corn silage. Revista Brasileira de Zootecnia, v.37, n.2, p.311-318, 2008. Available from: <http:// goo.gl/VqyOpa>. Accessed: Dec. 21, 2015. doi: 10.1590/S151635982008000200018 .

FERREIRA, I.C. et al. Technical and economic evaluations of different genetic groups of yearling beef cattle males and of the feedlot production system. Arquivo Brasileiro de Medicina Veterinária e Zootecnia, v.61, n.1, p.243-250, 2009. Available from: <http://goo.gl/wrUOjP >. Accessed: Nov. 11, 2015. doi: 10.1590/S0102-09352009000100034.
KASSAI, J.R. et al. Retorno de investimento: abordagens matemática e contábil do lucro empresarial. 3.ed. São Paulo: Atlas, 2007. 277p.

LOPES, M.A. et al. Economic analysis of the finishing of beef cattle in feedlots in the state of Minas Gerais: a case study. Revista Ceres, v.60, n.4, p.465-473, 2013. Available from: <http:/goo.gl/I1Ywle>. Accessed: Jan. 10, 2016. doi: 10.1590/S0034-737X2013000400004.

MELLO, R. et al. Bio-economicity of the finishing phase on feedlot of crossbred young bulls slaughtered at different body weights. Revista Brasileira de Zootecnia, v.38, n.1, p.109-121, 2009. Available from: <http://goo.gl/YrlsV6>. Accessed: Jan. 05, 2016. doi: 10.1590/S1516-35982009000100015.

MOREIRA, S.A. et al. Economic analysis of beef cattle feedlot finished within the dynamics of a farm. Custos e @gronegócio online, v.5, n.3, p.132-152, 2009. Available from: <http://goo. gl/8kSCeL > . Accessed: Jan. 20, 2016.

OLIVEIRA, C.A.; MILLEN, D.D. Survey of the nutritional recommendations and management practices adopted by feedlot cattle nutritionists in Brazil. Animal Feed Science and Technology, v.197, p.64-75, 2014. Available from: <http://goo.gl/PNups1>. Accessed: May 23, 2014. doi: 10.1016/j.anifeedsci.2014.08.010.

PACHECO, P.S. et al. Economic viability of feedlot finishing steers slaughtered with different weights. Pesquisa Agropecuária Gaúcha, v.18, n.2, p.135-145, 2012. Available from: <https://goo. gl/dSUocX>. Accessed: May 25, 2014.

PACHECO, P.S. et al. Economic deterministic analysis of feedlotfinished steers slaughtered at different weights. Ciência Animal Brasileira, v.15, n.4, p.420-427, 2014a. Available from: <http:/goo.gl/ ePV4Ly>. Accessed: 1 Feb, 2013. doi: 10.590/1089-6891v15i4257474.

PACHECO, P.S. et al. Economic analysis of finishing feedlot steers fed different proportions of sugar cane and concentrated. Semina: Ciências Agrárias, v.35, n.2, p.999-1012, 2014b. Available from: <http://goo.gl/SxCvUH>. Accessed: May 24, 2015. doi: 10.5433/1679-0359.2014v35n2p999.

RESTLE, J. et al. Economic evaluation of feedlot finished Red Angus young steers slaughtered with different weights. Revista Brasileira de Zootecnia, v.36, n.4, p.978-986, 2007. Available from: <http://goo.gl/ABTA6X>. Accessed: Jan. 10, 2016. doi: 10.1590/S1516-35982007000400030.

SOUZA, A.; CLEMENTE, A. Decisões financeiras e análise de investimentos: fundamentos, técnicas e aplicações. 6.ed. São Paulo: Atlas, 2009. 178p.

VALADARES FILHO, S.C. et al. Calculation of nutritional requirements and formulation of diets. Available from: $<$ http//:www.brcorte.ufv.br>. Accessed: Jan. 01, 2015.

VAZ, F.N. et al. Feedlot performance of young steers of different genetic groups Fabiano. Revista Ciência Agronômica, v.44, n.1, p.167-173, 2013. Available from: <http://goo.gl/Qn6s6F>. Accessed: Dec. 18, 2015. 